\title{
HUBUNGAN TINGKAT STRES DENGAN INDEKS MASSA TUBUH PADA MAHASISWA FAKULTAS KEDOKTERAN UNIVERSITAS KRISTEN INDONESIA
}

\author{
Jumaini Andriana ${ }^{1}$, Nur Nunu Prihantini ${ }^{2}$ \\ 1. Departemen Anatomi FK UKI \\ 2. Departemen Biokimia FKUKI
}

Email : nunuprihantini23@gmail.com

\begin{abstract}
ABSTRAK
Tingkat Stres seseorang berbeda- beda pada masing - masing individu dan merupakan masalah yang sering sulit untuk diselesaikan. Prevalensi terjadinya stres pada mahasiswa juga tinggi. Hal ini dapat mengancam efektifitas mahasiswa dalam menjalankan perkuliahannya sehingga kualitas belajar akan terganggu. Selain itu, pola makan juga dapat berpengaruh oleh karena stres. Penelitian ini bertujuan untuk mengetahui bagaimana hubungan tingkat stres dengan indeks massa tubuh pada mahasiswa fakultas kedokteran Universitas Kristen Indonesia. Penelitian ini merupakan penelitian analitik dengan penggunaan sampel sebanyak 117 orang. Pengumpulan data dilakukan dengan menggunakan kuesioner DASS 42 dan pengukuran berat badan serta tinggi badan menggunakan timbangan. Hasil penelitian ini menunjukkan bahwa sebagian besar mahasiswa FK UKI angkatan 2016 memiliki tingkat stres yang normal atau sekitar 76,9\% mahasiswa. Tingkat stres yang dialami mahasiswa FK UKI angkatan 2016 juga sebagian besar normal dengan jumlah 58 anak atau sekitar 49,6\%. Untuk mengetahui hubungan antar variabel, digunakan Uji korelasi Spearman. Kesimpulan didapatkan antara variabel tingkat stres dengan indeks massa tubuh tidak memiliki korelasi yang bermakna $\quad(p<0,5)$.
\end{abstract}

Kata kunci : Tingkat stres, indeks massa tubuh, mahasiswa kedokteran

\begin{abstract}
A person's Stress Levels vary by individual and are often difficult to solve. The prevalence of stress in students is also high. This can threaten the effectiveness of students in conducting their lectures so that the quality of learning will be compromised. In addition, diet can also be influential due to stress. This research aims to find out how stress levels are related to body mass index in medical faculty students of Universitas Kristen Indonesia. This research is an analytical study with the use of a sample of 117 people. Data collection was conducted using dass 42 questionnaires and weight and height measurements using scales. The results showed that the majority of FK UKI students in 2016 had normal stress levels or about 76.9\% of students. The stress level experienced by FK UKI students in 2016 is also mostly normal with the number of 58 children or about $49.6 \%$. To find out the relationship between variables, spearman correlation test is used. Conclusions obtained between variable stress levels and body mass index have no meaningful correlation ( $p<0.5)$.
\end{abstract}

Keyworrd: Stress levels, body mass index, Faculty of Medicine 


\section{PENDAHULUAN}

Stres merupakan kondisi yang dialami dalam kehidupan sehari-hari yang pernah dialami oleh semua orang. Dalam pengertian stres yang disampaikan oleh seorang ahli dan juga adalah penemu dari "Stress Theory" Hans Selye, yaitu merupakan respon non-spesifik dari tubuh terhadap pemicu nya atau yang disebut dengan stresor ${ }^{1}$. Respon yang ditimbulkan dapat merupakan respon secara mental dan emosional dari stimulus eksternal yang merugikan (stressor) yang mampu mengakibatkan gangguan pada kesehatan fisik yang biasanya dengan karakteristik meningkatnya tekanan darah atau juga bisa dengan ketegangan dari otot tubuh.

Apabila stres terjadi secara terus menerus dan berlangsung dalam jangka waktu yang lama, maka hal ini akan mempengaruhi berat badan, baik itu terjadi kekurangan berat badan maupun kelebihan berat badan. Stres merupakan hal yang tidak dapat dihindarkan dalam kehidupan seharihari termasuk dalam kehidupan di Fakultas kedokteran UKI. ${ }^{1,11,13}$

Indeks Massa Tubuh (IMT) merupakan ukuran yang digunakan untuk mengukur status gizi dengan cara membandingkan berat badan dan tinggi badan. Menurut pernyataan dari Departemen Kesehatan Indonesia, status gizi dikategorikan antara lain kurus dengan IMT $<17$, normal 17-25, kegemukan 25-27, dan Obesitas $>27$. Tentunya dengan dengan menilai status gizi, kita dapat menilai bagaimana stres mempengaruhi status gizi pada individu. Hal ini penting karena dengan status gizi yang kurang dapat menjadi faktor timbulnya penyakit infeksi sedangkan status gizi yang lebih dapat menjadi faktor timbulnya penyakit degeneratif. Selain itu, menurut penelitian yang dilakukan oleh
Waode ditemukan bahwa adanya hubungan status gizi dengan prestasi belajar ${ }^{2,9}$.

Pentingnya mengetahui bagaimana pentingnya tingkat stres dan indeks massa tubuh terhadap kesehatan fisik maupun mental, maka diadakan penelitian ini yang dilakukan pada mahasiswa kedokteran Fakultas Kedokteran Universitas Kristen Indonesia di Jakarta angkatan 2016.

\section{KAJIAN PUSTAKA}

Stres adalah suatu respon non spesifik dari tubuh atas kondisi yang terjadi di sekitar nya atau di lingkungan nya. Di dalam waktu tertentu di dalam hidupnya, manusia akan mengalami stres. Stres yang dialami bisa dalam bentuk yang menyenangkan maupun tidak. Stres merupakan kondisi yang berbeda dengan distress ataupun depresi namun masingmasing memiliki perbedaan tersendiri. Hawari (dalam Yusuf, 2004) berpendapat bahwa istilah stres tidak dapat dipisahkan dari distress dan depresi, karena satu sama lainnya saling terkait. Stres merupakan reaksi fisik terhadap permasalahan kehidupan yang dialaminya dan apabila fungsi organ tubuh sampai terganggu dinamakan distress. Sedangkan depresi merupakan reaksi kejiwaan terhadap stressor yang dialaminya ${ }^{3}$

\section{Penyebab Stres}

Penyebab terjadinya stres disebut stresor.Stresor merupakan berbagai macam bentuk hal yang menimbulkan tekanan pada individu sehingga menimbulkan respon terhadapnya yaitu stres. Asal dari stresor tersebut bisa dari luar atau disebut stresor eksternal maupun dari dalam yang disebut stresor internal. Stresor dari luar timbul dari adanya interaksi individu dengan lingkungannya. Hal tersebut bisa menimbulkan trauma bagi individu seperti contohnya kehilangan orang yang dicintai 
maupun juga kehilangan pekerjaan sedangkan stresor internal adalah contohnya kecemasan, marah, rasa bersalah yang bisa menimbulkan tekanan bagi individu ${ }^{2}$.

\section{Tanda dan Gejala Stres}

Tanda dan gejala stres berbeda-beda pada setiap individu karena itu, masingmasing individu dapat memberikan penilaian mengenai tanda dan gejala stres yang dialaminya. Tanda dan gejala stres dapat berupa gejala fisik maupun psikologis. Gejala fisik yang ditemukan pada individu yang mengalami stres meliputi tekanan darah yang meningkat, mudah lelah, berdebar-debar, mual, gangguan lambung, menstruasi terganggu, ekstremitas dingin, tremor, tegang otot, maupun napas pendek.

Gejala psikologis stres meliputi mudah marah, cemas, menurunnya rasa percaya diri, hipersensitif, kehilangan kreativitas, menarik diri dari pergaulan, menangis tiba-tiba, kehilangan konsentrasi, kehilangan minat terhadap bermacam hal yang disenangi dan mudah tersinggung. ${ }^{3}$

\section{Klasifikasi Stres}

Stres dibagi menjadi 3 klasifikasi yaitu stres ringan, stres sedang dan stres berat. ${ }^{4}$

\section{Stres ringan}

Stres ringan merupakan gejala stres yang tidak mengganggu fisiologis dari individu. Gejala ini biasanya hanya berupa gejalagejala ringan yang sering dialami setiap orang misalnya lupa atau tertidur saat beraktivitas

\section{Stres sedang}

Stres sedang merupakan gejala stres yang timbul hingga sampai beberapa jam hingga beberapa hari. Gejala stres sedang juga mengganggu fisiologis dari individu misalnya kurang konsentrasi, gangguan siklus menstruasi maupun gangguan pencernaan. Contoh stresor stres sedang adalah tugas yang terlalu berat atau gagal melakukan tanggung jawab dalam pekerjaan

\section{Stres berat}

Stres berat merupakan gejala stres kronis yang timbul dari beberapa hari hingga berbulan-bulan. Terjadi peningkatan gejala yang semakin berat daripada sebelumnya. Gejala yang timbul bisa berupa berdebardebar, berkeringat, ekstremitas kecemasan meningkat, mudah panik. Contoh stresor pada stres berat ini adalah kesulitan finansial, menderita penyakit yang sulit disembuhkan, maupun kegagalan dalam rumah tangga.

Pendidikan kedokteran merupakan salah satu program pendidikan dengan tingkat insidensi stres yang tinggi terutama pada mahasiswa tahun pertama. Hal ini dibuktikan dengan penelitian oleh Sherina dan rekan nya pada mahasiswa kedokteran di Malaysia dengan ditemukannya angka yang tingkat stres yang tinggi pada mahasiswa tahun pertama yaitu $66,2 \%$ pada mahasiswa wanita dan angka yang cukup tinggi pada mahasiswa pria yaitu 33,8\% . Pada penelitian yang dilakukan Abdulghani di Arab Saudi, diketahui bahwa prevalensi stres pada mahasiswa fakultas kedokteran adalah 57\%. Sejumlah 21,5\% mahasiswa mengalami stres ringan, 15,8\% stres sedang, dan $19,6 \%$ stres berat $^{5}$. Penelitian yang dilakukan oleh Viona pada mahasiswa kedokteran Universitas Tanjung Pura membuktikan bahwa adanya insidensi stres pada mahasiswa kedokteran yaitu yang bervariasi sebanyak $86,4 \%$ dari stres ringan sampai berat ${ }^{6}$.

Timbulnya stres dapat meningkatkan kadar hormon kortisol, dimana hormon kortisol ini berperan untuk regulasi penyimpanan lemak sehingga tubuh akan lebih banyak untuk menyimpan lemak dan juga memberi stimulus lapar ke otak yang dapat dilihat pada penelitian oleh Chao bahwa peningkatan kadar kortisol sejalan dengan peningkatan berat badan ${ }^{7}$.

\section{Tingkat Stres}


Tingkat stres dapat dinilai ringan, sedang, maupun berat diukur dengan menggunakan Depression Anxiety Stress Scale 42 (DASS 42) dari Lovibond \& Lovibond (1995) yang terdiri dari 42 pertanyaan. DASS 42 merupakan skala subjektif yang dapat digunakan untuk mengukur status emosional negatif dari depresi, kecemasan dan stres. Tingkatan stres pada instrumen ini berupa normal, ringan, sedang, berat, sangat berat. Depression Anxiety Stres Scale 42 (DASS) terdiri dari 42 item, mencakup 3 subvariabel, yaitu fisik, emosi/psikologis, dan perilaku. Jumlah skor dari pernyataan item tersebut, dinilai dari 0-29 (normal); 30-59 (ringan); 60-89 (sedang); 90-119 (berat); >120 (Sangat berat $)^{8,15}$

Indeks massa tubuh (IMT) adalah alat sederhana untuk memantau status gizi pada orang dewasa. IMT di tentukan dengan cara menghitung berat badan dalam kilogram dibagi dengan tinggi badan dalam meter kuadrat $(\mathrm{kg} / \mathrm{m} 2)$. IMT dapat digunakan sebagai indikator atau mengambarkan kadar adipositar dalam tubuh seseorang. WHO merekomendasikan untuk mengklasifikasikan berat badan, termasuk katagori berat badan kurang hingga berat badan lebih yang berkaitan dengan resiko penyakit tidak menular. ${ }^{10}$

Faktor yang mempengaruhi IMT Ada beberapa faktor yang mempengaruhi IMT : ${ }^{12}$
a. Kebiasaan makan
b. Aktivitas Fisik
c. Asupan Energi, Protein, Karbonhidrat, dan Lemak. 


\section{METODOLOGI PENELITIAN}

Penelitian ini adalah penelitian analitik observasional yang dilaksanakan dengan melakukan pendekatan cross sectional untuk memulai antara Hubungan Tingkat Stress dengan Indeks Massa Tubuh. PPenelitian dilakukan di Fakultas Kedokteran Universitas Kristen Indonesia dengan menggunakan kriteria inklusi dan ekslusi. Teknik pengambnilan sampel dilakukan dengan cara simple random sampling dengan semua mahasiswa yang memenuhi kriteria inklusi dapat mengikuti penelitian ini. Pada Penelitian ini, besar sampel akan dihitung dengan menggunakan rumus Slovin dengan penghitungan sebagai berikut:

Keterangan :

$$
n=\frac{\mathrm{N}}{1+\mathrm{N} e^{2}}
$$

n : Besar sampel

$\mathrm{N} \quad$ : Populasi $=166$

e $\quad$ : Margin of Error $=5 \%(0,05)$

$$
\begin{gathered}
n=\frac{166}{1+\left(166 \cdot(0,0025)^{2}\right.} \\
n=\frac{166}{1,415} \\
\mathrm{n}=117,314488=117
\end{gathered}
$$

Subyek penelitian adalah perempuan dan laki - laki data diperoleh dengan menggunakan kuesioner untuk mengetahui tingkat stres dari sampel sedangkan timbangan akan digunakan untuk mengukur berat badan serta tinggi badan untuk menetukan indeks massa tubuh. Sebelum melakukan penelitian dilakukan prosedur informed consent kepada subyek penelitian.

Kriteria Sampel

Kriteria inklusi adalah kriteria dimana subjek penilaian dapat mewakili dalam sampel penelitian yang memenuhi syarat sampel. Kriteria inklusi dalam penelitian ini adalah:

1. Mahasiswa kedokteran dengan umur 20 - 23 tahun.

2. Sehat jasmani dan rohani.

3. Bersedia mengisi kuisioner.

\section{Indeks Massa Tubuh}

Indeks Massa Tubuh merupakan standar yang digunakan WHO untuk menentukan status gizi dari individu dengan menggunakan perbandingan dari tinggi badan dan berat badan. Penilaian dilakukan dengan menggunakan rumus berikut: ${ }^{14}$

$$
\mathrm{IMT}=(\mathrm{BB}(\mathrm{Kg})) /(\mathrm{TB}(\mathrm{m}) \times \mathrm{TB}(\mathrm{m}))
$$

\section{Gambar II.1 Rumus menghitung IMT}


IMT : Indeks Massa Tubuh

BB : Berat badan $(\mathrm{Kg})$

TB : Tinggi badan $(\mathrm{Kg})$

Dari hasil perhitungan tersebut akan didapatkan skor yang dapat di interpretasikan sebagai berikut:

Tabel .1 Interpretasi penghitungan $\mathrm{IMT}^{15}$

\begin{tabular}{lll}
\hline No & Indeks Massa Tubuh & Nilai \\
\hline 1 & Kurang & $<18$ \\
2 & Normal & $18,5-22,9$ \\
3 & Beresiko Obesitas & $23-24,9$ \\
4 & Obesitas 1 & $25-29,9$ \\
5 & Obesitas 2 & $>=30$ \\
\hline
\end{tabular}

Nilai IMT tersebut berhubungan dengan faktor risiko kesehatan yang dapat dialami oleh individu. Misal seorang individu memiliki IMT 18,5 dapat dikatakan individu akan memiliki faktor resiko kesehatan seperti mudah mengalami infeksi dikarenakan nutrisi yang sangat kurang. Pada IMT yang lebih dari 30 disebut obesitas juga memiliki faktor resiko penyakit degeneratif contohnya meningkatnya tekanan darah yang dapat mengakibatkan serangan jantung.

\section{Analisis Data}

Analisis Univariat

Digunakan untuk mengetahui persentase dari hasil setiap variabel yang disampaikan.

\section{Analisis Bivariat}

Analisis bivariat dilakukan untuk melihat adanya hubungan antara variabel dependen dengan variabel independen. Uji hipotesis yang digunakan untuk hasil akhir penarikan kesimpulan adalah dengan menggunakan uji analisis hubungan Pearson jika data terdistribusi normal, bila data tidak terdistribusi normal maka menggunakan uji analisis hubungan Spearman-rho.

$n=\{Z \propto+Z \beta 0,5 \ln (1=r) /(1-r)\}^{2}+3$

Keterangan $\mathrm{n}$ : jumlah sampel $Z \propto$ : nilai $\mathrm{Z}$ untuk tingkat kepercayaan (biasanya IK 95\%) $Z \beta$ : nilai Z untuk power test (biasanya 89\%) r : perkiraan koefisien korelasi

\section{HASIL DAN PEMBAHASAN}

Penelitian ini menggunakan uji statistik parametrik yaitu uji hubungan Pearson untuk mengetahui hubungan tingkat stress terhadap indeks massa tubuh pada mahasiswa fakultas kedokteran Universitas Kristen Indonesia. Jumlah sampel dalam penelitian ini sebanyak 91 orang yang terdiri dari responden laki-laki 37 orang dan perempuan 80 orang. Namun sebelum data diolah menggunakan uji statistik parametrik maka data yang digunakan harus lolos uji asumsi terlebih dahulu yaitu uji normalitas.

Karakteristik subyek penelitian $(\mathrm{N}=117)$

\begin{tabular}{lll}
\hline Karakteristik & n & $\%$ \\
\hline
\end{tabular}




\section{Jenis Kelamin}

Laki - Laki

Perempuan

80

68.4

Usia

20

19.7

21

\section{Indeks Massa Tubuh}

Berat Badan Kurang $(<18,5)$

Normal (18.5-22.9)

Beresiko Obesitas( 23-22.9

Obesitas 1 (25-29.9)

Obesitas 2 (2 (>=30)

17.1

Tingkat Stress

Normal (0-14)

7.7

Stres Ringan (15-18)

Stres sedang (19-25)

9.4

Stres Berat (26-33)

10.3

Stres sangat berat $(>34)$

Jumlah subyek penelitian laki - laki sebanyak 37 orang (31.6\%), sedangkan perempuan sebanyak 80 orang $(68.4 \%)$ sehingga jumlah keseluruhan adalah 117 orang. Subyek penelitian ini sebagian besar orang yang berusia 21 tahun sebanyak 58 orang (49.6\%).

Dari data diperoleh Berdasarkan IMT didapatkan sekitar 49.6 \% dalam kategori IMT normal, IMT diikuti jumlah subyek penelitian terbanyak kedua adalah IMT beresiko obesitas $17.9 \%$ sedangkan IMT kategori obesitas 1 sebesar 17.1\%, IMT obesitas 2 sebesar $7.7 \%$.

Distribusi Frekuensi Berdasarkan Variabel Tingkat Stres Pada Responden Jenis Kelamin Laki - laki

\begin{tabular}{llc}
\hline Tingkat Stres & Jumlah & Persentase $(\%)$ \\
\cline { 2 - 2 } & Laki-laki & \\
\hline Normal & 28 & 75,7 \\
Stres ringan & 3 & 8,1 \\
Stres sedang & 5 & 13.5 \\
Stres berat & 1 & 2.7 \\
Stres sangat berat & 0 & 0 \\
\hline Total & 37 & 100
\end{tabular}

Distribusi Frekuensi Berdasarkan Variabel Tingkat Stres Pada Responden Jenis Kelamin Perempuan 


\begin{tabular}{lll}
\hline Tingkat Stres & Jumlah & Persentase \\
\cline { 2 - 2 } & Perempuan & \\
\hline Normal & 62 & 77.3 \\
Stres ringan & 8 & 10 \\
Stres sedang & 7 & 8.7 \\
Stres berat & 2 & 2.5 \\
Stres sangat berat & 1 & 1.5 \\
\hline Total & 80 & 100
\end{tabular}

Distribusi Frekuensi Berdasarkan Variabel Tingkat Indeks Massa Tubuh Pada Responden Jenis Kelamin Laki - Laki.

\begin{tabular}{lll}
\hline Indeks Massa Tubuh & Jenis Kelamin & Persentase \\
\hline Berat badan kurang & 2 & 5.4 \\
Normal & 13 & 35.1 \\
Beresiko Obesitas & 10 & 27 \\
Obesitas 1 & 7 & 18.9 \\
Obesitas 2 & 5 & 13.5 \\
\hline Total & 37 & 100 \\
\hline
\end{tabular}

Distribusi Frekuensi Berdasarkan Variabel Tingkat Indeks Massa Tubuh Pada Responden Jenis Kelamin Perempuan

\begin{tabular}{lll}
\hline Indeks Massa Tubuh & Jenis Kelamin & Persentase(\%) \\
\hline Berat badan kurang & 7 & 8.7 \\
Normal & 45 & 56.3 \\
Beresiko Obesitas & 11 & 13.7 \\
Obesitas 1 & 13 & 16.3 \\
Obesitas 2 & 4 & 5 \\
\hline Total & 80 & 100 \\
\hline
\end{tabular}

Hubungan Tingkat Stress dengan Indeks Massa pada Responden Jenis Kelamin Laki-laki

\begin{tabular}{llllll}
\hline Variabel & Mean & SD & Min & Max & P-value \\
\hline
\end{tabular}




\begin{tabular}{lllrrr}
\hline Tingkat Stress & 7,4 & 4,28 & 2 & 13 & 0,61 \\
Indeks Massa Tubuh & 7,4 & 11,67 & 28 & 0 &
\end{tabular}

Berdasarkan tabel di atas, dapat dipaparkan hasil analisis hubungan tingkat stress terhadap indeks massa tubuh pada responden laki-laki menggunakan uji Pearson Product Moment diperoleh nilai $\mathrm{p}=0,61$. Berdasarkan hasil analisis dapat diketahui bahwa jika nilai $\mathrm{p}>0.05$, dalam hal demikian berarti Ha ditolak sehingga dapat disimpulkan bahwa tidak terdapat hubungan yang signifikan antara tingkat stres terhadap IMT pada mahasiswa FK UKI.

Hubungan Tingkat Stress dengan Indeks Massa Tubuh pada Responden Jenis Kelamin Perempuan

\begin{tabular}{lccccc}
\hline Variabel & Mean & SD & Min & Max & P-value \\
\hline Tingkat Stress & 16 & 16,58 & 4 & 45 & 0.221 \\
Indeks Massa Tubuh & 16 & 25,89 & 2 & 62 & \\
\hline
\end{tabular}

Berdasarkan tabel di atas, dapat dipaparkan hasil analisis hubungan tingkat stress terhadap indeks massa tubuh pada responden laki-laki menggunakan uji Pearson Product Moment diperoleh nilai $\mathrm{p}=0,221$. Berdasarkan hasil analisis dapat diketahui bahwa jika nilai $\mathrm{p}>0.05$, dalam hal demikian berarti Ha ditolak sehingga dapat disimpulkan bahwa tidak terdapat hubungan yang signifikan antara tingkat stres terhadap IMT pada mahasiswa FK UKI. 


\section{Kesimpulan}

Kesimpulan Penelitian yang telah dilakukan pada mahasiswa FK UKI korelasi tingkat stres dengan IMT dapat disimpulkan bahwa:

1. Tidak ada korelasi antara IMT pada mahasiswa laki - laki dan perempuan.

2. Sebanyak $35,1 \%$ mahasiswa FK UKI laki laki di realisasikan normal, termasuk sebanyak

$56,3 \%$ normal pada wanita.

3. Sebanyak $5,4 \%$ mengalami kekurangan berat badan pada laki - laki , sedangkan pada

Perempuan kurus yaitu $8,7 \%$.

\section{Saran-saran}

Penelitian ini dapat menjadi sebuah pembelajaran baru untuk proses penelitian yang akan dilakukan selanjutnya untuk lebih cermat dan tepat dalam melakukan pemilihan sampel. Serta dapat menjadi rujukan bagi peneliti selanjutnya yang akan melakukan penelitian mengenai stress dan indeks massa tubuh.

\section{DAFTAR PUSTAKA}

1. Selye, H. (1946). The general adaptation syndrome and the diseases of adaptation. The journal of clinical endocrinology, 6(2), 117230

2. Udu, Waode Siti Asfiah. Hubungan Status Gizi dengan Prestasi Belajar Siswa Sekolah Dasar. Bagian Kedokteran Komunitas Universitas Haluleo. 2013; 36-40

3. Hawari, Dadang. Manajemen Stress, Cemas, Depresi.Jakarta: FKUI (2006).

4. Maramis WF, Maramis AA. Catatan ilmu kedokteran jiwa edisi 2. Surabaya: Pusat Penerbitan dan Percetakan (AUP). 2009 : 38

5. Abdulghani, H. M. Stress and depression among medical students: A cross sectional study at a medical college in Saudi Arabia. Pakistan journal of medical sciences.2008.24(1), 12.
6. Viona V. Hubungan antara Karakteristik Mahasiswa dengan Kualitas Tidur pada Mahasiswa Program Studi Pendidikan Dokter Fakultas Kedokteran Universitas Tanjungpura. Jurnal Mahasiswa Fakultas Kedokteran Untan.;1(1).

7. Chao AM, Jastreboff AM, White MA, Grilo CM, Sinha R. Stress, cortisol, and other appetite-related hormones: Prospective prediction of 6-month changes in food cravings and weight. Obesity. 2017 Apr;25(4):713-20.

8. Suganda, Kevin Dilian. Tingkat Stres pada Mahasiswa Tahun Pertama Fakultas Kedokteran Universitas Sumatera Utara Angkatan 2013. Jurnal Universitas Sumatera Utara.2014;

9. Sherina MS, Rampal L, Kaneson N. Psychological stress among undergraduate medical students. Malaysia Medical Journal. 2004;59(11):207-10.

10. Hasil Pemantauan Gizi Seimbang ( PSG ) . Kemenkes.go.id; 2017.

11. Abdulghani, H. M. Stress and depression among medical students: A cross sectional study at a medical college in Saudi Arabia. Pakistan journal of medical sciences.2008.24(1),

12. Hartyaningtyas GY. Faktor-faktor yang mempengaruhi Indeks Massa Tubuh ( IMT ) Pada Siswa SMA Marsudirin Bekasi. 2013.

13. Viona V. Hubungan antara Karakteristik Mahasiswa dengan Kualitas Tidur pada Mahasiswa Program Studi Pendidikan Dokter Fakultas Kedokteran Universitas Tanjungpura. Jurnal Mahasiswa Fakultas Kedokteran Untan.;1(1).

14. Konsep Stres. Universitas Sumatera Utara. Diunduh dari http://repository.usu.ac.id pada 12 Oktober 2018

15. Elkin AJ, Rosch PJ. Promoting mental health at the workplace: the prevention side of stress 
management. Occupational Medicine

(Philadelphia, Pa.). 1990;5(4):739-54. 